\title{
Private Participation in Infrastructure Projects in the Republic of Korea
}

\author{
Paul Noumba UM** and Severine Dinghem ${ }^{1}$ \\ The World Bank \\ 1818 H Street, NW \\ Washington DC 20433 USA \\ Pnoumbaum@worldbank.org-Sdinghem@worldbank.org
}

\begin{abstract}
:
In the aftermath of the 1997 East-Asian financial crisis, the government of the Republic of Korea published a Private Participation in Infrastructure (PPI) Act in order to remove the main impediments to private investment in infrastructure sectors. The implementation of the Act was followed by a steady increase in the number of PPI projects, thus spurring the modernization of the main infrastructure facilities in transport, water, electricity and telecommunications. Despite this progress, the Korean PPI market still faces critical challenges that are probably related to its nascent stage of development. The market is dominated by five construction and engineering firms, but lacks world-class project developers. At the same time, the procurement of PPI projects takes on average four years, and competition in tenders is limited. The number of unsolicited proposals is abnormally high, whereas the number of solicited proposals remains flat. The participation of foreign firms is very limited despite the size of the market and the number of projects awarded. Although local financing is available, the maturity of financing instruments does not exceed five years for most corporate papers, and ten years for government bonds. This paper reviews the procurement of PPI projects in Korea and benchmarks it to international best practices before proposing options for its improvement.
\end{abstract}

World Bank Policy Research Working Paper 3689, September 2005

The Policy Research Working Paper Series disseminates the findings of work in progress to encourage the exchange of ideas about development issues. An objective of the series is to get the findings out quickly, even if the presentations are less than fully polished. The papers carry the names of the authors and should be cited accordingly. The findings, interpretations, and conclusions expressed in this paper are entirely those of the authors. They do not necessarily represent the view of the World Bank, its Executive Directors, or the countries they represent. Policy Research Working Papers are available online at http://econ.worldbank.org.

\footnotetext{
** Please send your comments or requests to pnoumbaum@worldbank.org.

${ }^{1}$ Severine Dinghem is a senior financial specialist with the Infrastructure Economics and Finance department (IEF) of the World Bank and Paul Noumba Um is a lead infrastructure specialist with the World Bank Institute (WBI). The paper draws on a research project conducted at the request of the Private Infrastructure Investment Facility of Korea (PICKO) between August and November 2004. A previous version of the paper was published in PICKO (2004), Developing best practices for Korea's PPI market: with a focus on PSC, pp 200-36. We are grateful to Alexander Fleming, Michael Jarvis, Jeffrey Gutmann, Dr Jay Kim, Ms Junglim Hahm and two anonymous reviewers for their comments and suggestions.
} 


\section{Introduction}

In the aftermath of the 1997 East Asian financial crisis, the government of the Republic of Korea published a private participation in infrastructure (PPI) Act in order to remove the main impediments to private investment in infrastructure sectors. The implementation of the Act was followed by a steady increase in the number of PPI projects, thus spurring the modernization of the main infrastructure facilities in transport, water, electricity and telecommunications. Despite this progress, the Korean PPI market still faces critical challenges that are probably related to its nascent stage of development. The market is dominated by five construction and engineering firms, but lacks world-class project developers. At the same time, the procurement of PPI projects takes on average four years, and competition in tenders is limited. The number of unsolicited proposals is abnormally high, whereas the number of solicited proposals remains flat. The participation of foreign firms is very limited despite the size of the market and the number of projects awarded. Although local financing is available, the maturity of financing instruments does not exceed five years for most corporate papers, and ten years for government bonds (Dailami, 2004).

The paper reviews the procurement of PPI projects in Korea and benchmarks it to international best practices before proposing options for its improvement. However, the paper does not thoroughly review the legal, institutional, capacity building and policy aspects that encompass the procurement of PPI projects. The remainder of the paper is organized in two sections. The first section begins by reviewing specific characteristics of PPI projects before discussing the main issues that are likely to affect the success of PPI project tenders. Section 2 reviews the development of PPI projects in Korea and more specifically discusses how these projects should be procured in order to achieve the development objectives.

\section{International experience in the procurement of PPI projects}

PPI projects are not contemporary innovations. King Henry II of France granted the first PPI project to an individual, Adam de Craponne, for the construction of a canal in 1554. 
The United Kingdom has granted operating licenses since 1609 (Spiller and Vogelsang, 1993). These licenses were initially granted by the King and the parliament subsequently took over this role. There are also many examples supporting private sector involvement in the development of infrastructure facilities and related services in developed and developing countries. For example, in the early days of the industrial revolution, many governments (local or central) granted concessions to the private sector for the construction and operation of public facilities such as canals, railroads, roads, bridges, and utilities. Overall, PPI projects developed on a large scale as early as the beginning of the $19^{\text {th }}$ century along with the diffusion of utility services to households. This section reviews the main characteristics of PPI projects before discussing issues affecting their procurement. The section provides examples and references to international best practices observed in the procurement of PPI projects during the past 15 years.

\section{A. Specific characteristics of PPI projects}

In this paper, we define PPI projects as rights granted by governments (central, state or local) to private parties in order to build and operate infrastructure facilities to provide a set of defined services during a period of time and receive associated revenues. As defined here, PPI projects may or may not involve pre-existing government assets and entail the issuance by governments of concession contracts or operating licenses. Consequently, the procurement of PPI projects is identical to the procurement of infrastructure concessions even though the latter term may have different meanings depending on the country's legal tradition or endowment. For instance, in civil law

countries such as France, the term concession is often associated to service delegations involving the construction and the operation of public facilities such as roads, railways, water, electricity and telecommunications. However, there is a fundamental difference between the procurement of PPI projects and the procurement of civil works. The paper assumes that the procurement of civil works involves construction or maintenance contracts. On the contrary, the procurement of PPI projects involves the construction and operation of infrastructure facilities in order to provide specified services. A second difference stems from the fact that PPI projects fall within the regime of private law 
contracts $^{2}$, whereas civil works are governed by administrative law contracts. Private law contracts ensure equivalent rights and obligations to contracting parties. For example, a private contract cannot be changed unless both parties agree to do so. Similarly, parties rely on the judiciary to protect their rights in case of a breach of contract. Conversely, administrative contracts are asymmetric in the sense that governments will usually have exorbitant rights. For example, governments will not need a judiciary decision before modifying or canceling a civil work contract or enforcing penalties in case of default.

Besides, infrastructure networks exhibit characteristics of natural monopoly. A highway linking city A to city B may be the only economically available route between these two cities. If conceded to a private entity, the concessionaire will hold a natural monopoly over the roadway between cities A and B even if the provision of transportation services remains competitive. The same applies to the distribution of water and electricity services. When a city decides to grant the distribution of water or electricity services to one concessionaire, there is little room left to develop competition in the market. Granting concessions in infrastructure sectors therefore entails monopoly or exclusive rights. In order to minimize monopoly rents captured by concessionaires, Sir Edwin Chadwick recommended in 1859 to promote wherever possible "competition for the market”. He went on recommending that concessions rights be auctioned to the bidder offering the most attractive terms - for example the lowest price to consumers. In resurrecting Chadwick's idea, Harold Demsetz (1968) advocated in favor of periodic rebidding of concession contracts in order to extract monopoly rents prevailing after the concession has been awarded. But one has to admit that re-bidding is not always a practical solution specially when assets are very specific to the concession or cannot be easily disbanded in a secondary market. In such a situation, re-bidding is not a practical solution $^{3}$ because of critical incentives problems that arise (Laffont and Tirole, 1993;

\footnotetext{
${ }^{2}$ For example, the government may have the privilege to terminate the contract at any time without relying on a judiciary decision. This is the case in most civil law countries such as France.

${ }^{3}$ In France, only $12 \%$ of the incumbent water concessionaires lost their renewing bids in 2000 (see ENGREF, 2001) compared to 8\% in 1998 and 18\% in 1999. Due to the limited terms of delegation contracts (on average 11 years in water concession or lease), ENGREF has found that out of 336 renewing contracts in 2000: (a) independent operators won 8 new contracts, (b) altogether the three main private
} 
Williamson 1976). Conversely, when assets are not specific to the concession, re-bidding can be a practical solution to the monopoly problem. For example, garbage collection concessions are often re-bid periodically. If the incumbent loses, she can simply transfer assets and staff to another purpose.

Most contemporary PPI projects are therefore procured using competitive tenders or standard auctions, but what differentiates auctions from tenders is hard to say. In this paper, we define a tender as a competitive bidding process that reflects one or a combination of the features discussed in Box 1. For instance, the sale of new rights in oil, gas, mining and telecommunications sectors (spectrum blocks, oil exploration permits, minerals concessions, etc.) is often based on ascending or first price sealed-bid auctions. But, there are specific circumstances, such as natural disasters, for which governments are probably better off negotiating directly with a restricted number of preferred bidders. However, direct negotiations are time consuming and require specialized skills that most governments in developing countries do not have. For example, it took the government of Morocco four years to close a "gré à gré" agreement for the Casablanca water concession, whereas the Tétouan - Tanger (Morocco) water concessions which were granted using a competitive tender were closed in 15 months.

water operators (Ondeo, Veolia, Saur) won $89 \%$ of the renewing contracts. Overall, the renewing procedure has ended in a change of operator only in $12 \%$ of the cases. 


\section{Box 1: Main types of auctions.}

- $\quad$ Ascending (English) and descending (Dutch) auctions are oral - open auctions, whereas first and second price auctions are sealed-bid auctions.

- In ascending auctions, the price is successively raised until only one bidder remains, and that bidder wins the object at the final price.

- On the contrary, in descending auctions, the seller starts at a very high price and lowers the price continuously. The first bidder who calls out and accepts the current price wins the object at that price.

- In first price sealed-bid auctions each bidder independently submits a single bid without seeing others' bids. The object is sold to the bidder who makes the highest bid.

- In second price sealed-bid auctions, each bidder independently submits a single bid without seeing others' bids and the object is sold to the bidder who makes the highest bid whereas she will pay the object at the price proposed by the second highest bid.

- In fact, many variants of auctions exist. For instance, the Anglo-Dutch auction combines the English auction and the first price sealed-bid auction to give an hybrid auction which captures the best features of both. In Anglo-Dutch auctions, the seller begins by running an ascending auction in which the price is raised continuously until all but two bidders have dropped out. The two remaining bidders are then asked to make a final sealed-bid offer that is not lower than the current asking price, and the winner pays this price.

\section{B. Main issues in bidding out PPI projects}

This sub-section primarily focuses on critical issues which are likely to deter the success of competitive tenders organized to procure PPI projects. The sub-section does not discuss broader institutional issues such as setting-up PPI units, developing legislation to promote PPI, or ensuring effective inter-governmental coordination. The sub-section more specifically addresses the following issues: encouraging participation and competition in bidding, ensuring certainty and predictability in the bidding process, ensuring the adequacy of the bidding process to the political and social context, ensuring effective regulation after the project has been awarded, and selecting a bidding process which can better address most of these concerns.

\section{Participation and competition in bidding}

A good tender should encourage the participation of credible bidders. Whether the goal is economic efficiency, maximum revenues or lowest costs, competition in tenders is necessary but not sufficient to achieve the development outcomes attached to PPI projects. One of the important deterrents to competition in tenders is the high cost of preparing compliant bids. The costs of preparing compliant bids include the costs 
associated with the hiring of financial, legal, technical and economic advisors. These costs can be as high as US\$5million for complex or large scale projects.

There is a correlation between the time allowed to prepare compliant bids and the quality of bids submitted, but, the lengthier becomes the bidding process, the higher are uncertainties faced by bidders. Tender rules and procedures should therefore reconcile the need to provide enough time for the preparation of compliant bids, and the need to complete the bidding process in a reasonable timeline. Tender documents should therefore provide accurate and consistent specifications about the service to be provided by the project developer. But, it is important to bear in mind that the procurement of PPI projects is a time consuming process. In Europe, the average timeline observed for light rail or road concession projects varies between 72 to 88 weeks ${ }^{4}$. In South Africa, PPI procurement guidelines recommend a timeline between 34 and 90 weeks. Clearly, the issue at stake is to implement a streamlined bidding process which is supported by clear and sound rules and procedures ${ }^{5}$. In the case of the desalination water Build Operate and Transfer (BOT) project in Israel (see Box 2), the government completed the process in 52 weeks, even though the two-stage bidding process included a third round during which preferred bidders had to submit their best available final offers.

For complex and very costly projects, it is often argued that governments should reimburse a portion or the totality of bids' preparation costs. There is no conclusive recommendation on this sensitive issue although it is important to restate the rule of thumb that bids should be prepared at bidders' costs and risks. However, in specific circumstances, the government can consider reimbursing a portion of the bids' preparation costs. For example, some years ago the Greek government agreed to reimburse bidding preparation costs to unsuccessful bidders participating to the tender

\footnotetext{
${ }^{4}$ A study published by the European Union finds that the average procurement time was: (a) 22.3 months for Tram and light rail PPI projects (upper bound: 30 months, Lower bound: 13 months), (b) 18 months for roads PPI projects (upper bound: 20, lower bound: 15). Source: Official Journal of European Communities. ${ }^{5}$ One anonymous reviewer suggests that the emphasis should be on the process of bid evaluation and contract award, because a protracted process of bid evaluation could undermine the transparency of the tender. We think that a streamlined bidding process underlined by sound rules and procedures will not only preserve bids' sanctity but will also ensure bidding predictability, and certainty, and should allow enough time for the evaluation of competing bids.
} 
organized for the concession of the Athens airport ${ }^{6}$. In South Africa, PPP guidelines recommend inversely reimbursing a portion of bids’ preparation costs only to bidders submitting compliant bids.

\author{
Box 2: Timeline of the Ashkelon BOT project in Israel \\ In 2001 the Water Desalination Authority (WDA) launched a 24-year and 11-month BOT tender for the \\ construction and the operation of a 50 million $\mathrm{m}^{3}$ desalination plant in Ashkelon. The plant capacity was to \\ be off-taken by the government of Israel. After a pre-qualification stage, three major international players \\ involving local firms were selected to participate in the final bidding stage as outlined below: \\ - February 2001 (end of Month 1): Issuance of the final BOT agreement \\ - Month 4: Initial date of Bid submission \\ - Mid- month 7: Bid submission \\ - Month 8: Best And Final Offer (BAFO) and the project was awarded to Vivendi Water (now Veolia) the \\ very same day \\ - Month 11: Selection of the arranger \\ - Month 12: Extension of the project scope to $100,000,000 \mathrm{~m}^{3}$ by authorities \\ - Month 13: Signature of the BOT Agreement; finalization of detailed design by the project's sponsors \\ - Month 25: Financial close; start of construction. \\ Source: Veolia Water (2003)
}

\title{
2. Certainty and predictability of the bidding process
}

Bidders dislike uncertainties. In general, most of the uncertainties observed in bidding processes stem from loopholes included in bidding procedures or documents. Bidders spend time and resources to review bidding documents while preparing their bids. The more bidding documents include loopholes or inconsistencies, the costlier becomes the preparation of compliant bids. Furthermore, bidders also exploit these inconsistencies and loopholes to their advantage as illustrated in Box 3.

\begin{abstract}
Box 3: Telecom auction in Turkey
In 2000, Turkey auctioned two telecom licenses sequentially with an additional twist that set the reserve price for the second license equal to the selling price of the first. One firm then bid far more for the first license than it could possibly be worth if the firm had to compete in the telecommunications market with a rival holding a second license. The firm had rightly figured out that no rival would be willing to bid that high for the second license which therefore remained unsold - leaving the first firm without a rival operating the second license. The main uncertainty in this bidding process came from the auction design: sequential award of two licenses but at the same price.
\end{abstract}

Source: adapted from Klemperer (2002 b)

\footnotetext{
${ }^{6}$ The initial capital costs for this project were estimated at US\$750 million (World Bank, 1998) and the government reimbursed up to US\$2million.
} 
Bidding is a non-cooperative game that involves at least three parties. The main party is naturally the authority organizing and setting the rules and procedures of the tender. The second party involves potential bidders competing for the project. The third party is represented by the lenders. Lenders provide financial resources in terms of debt or equity, and will not do so unless they are provided with sufficient guarantees of the project's ability to service debt and yield a reasonable rate of return.

To ensure certainty and predictability in the bidding process, tender rules and procedures should not be changed after the invitation for tenders has been issued. Certainty in bidding is equivalent to ensuring the "sanctity of the tender rules and procedures". This is done through transparent decision making and robustness, consistency and completeness of the tender rules and procedures. Moreover, tender rules and procedures should ensure the selectivity of the bidding process. Selectivity in the bidding process is of primary importance to ensure that the outcomes of the project will be delivered to consumers and to the economy. But selecting a capable developer is not enough. The regulatory framework should also restrain the government and the winner's ability to engage in future renegotiations. Indeed, the likelihood of renegotiations encourages opportunistic bidding strategies and undermines the need to organize a competitive tender in the first place (Guasch, 2004). A sound and effectively implemented bidding process should also impair bidders' ability to collude. As shown in Box 4, this is less than obvious. For instance, the collusion case reported by Klemperer (2002) was facilitated by the auction design (simultaneous ascending auction) implemented for the 3-G licenses. 
Box 4: New generation telecom licenses in Germany

Klemperer (2002) provides a complete review of the 3G licenses auctioned by many European governments in the early 2000s. For instance, the German government decided to use a simultaneous ascending auction to sell ten blocks of spectrum rights. The auction rules strictly stated that any new bid on a spectrum block had to exceed the previous high bid by at least 10 percent. Mannesman, one of the bidders participating in this auction, bid 18.18 million DM per megahertz for blocks 1 to 5 and 20 million DM per megahertz for blocks 6 to 10. T-Mobile, a competing bidder, interpreted the Mannesman's bid for blocks 1 to 5 as an offer although there was no explicit agreement between the two firms. It seems that T-Mobil understood that if it bid 20 million DM per MHz on blocks 1 to 5, and did not bid on blocks 6 to 10, the two firms would then live with neither company challenging the other on the other's half.

Source: adapted from Klemperer (2002)

\section{Adequacy of the tender design to the social and political context}

A good tender must reflect the socio-political context of the country as well as the peculiarities of the project. The procurement of PPI projects is politically sensitive. Because, PPI agreements are structured as risk sharing mechanisms, they are perceived as rent sharing mechanisms through which rents are redistributed between the project developer, the lenders, the government and eventually the consumers. The main rationale for organizing competitive tenders is to ensure fairness and equity in the way the rents are redistributed. Competitive tenders are therefore vulnerable to challenges brought by political opponents or social activists. Box 5 highlights such a situation in the case of the Cochambaba water concession project in Bolivia. Similar situations have been observed in many other countries ${ }^{7}$. In Algeria the second GSM license was caught up in political turmoil less than two years after being awarded because of the inability of the winner to quickly develop the services (Noumba, P., 2004). Similarly, the privatization of the power company in Senegal was terminated less than a year after being issued by the incoming government because of deficient performances. There are many other examples illustrating the political sensitivity of the concession of PPI projects. Competitive and transparent tenders can mitigate these political and social risks, but are not often sufficient to completely mitigate these risks. How to explain such mismatch? First, consumers and politicians have short terms goals, and make the most of their decisions on the basis of these short term goals, whereas the development of infrastructure projects

\footnotetext{
${ }^{7}$ The government of New Zealand implemented a second price sealed-bid auction to sell radio spectrum. In one extreme case, the first bid proposed NZ\$100,000 while the second bid only proposed NZ\$ 6 . The government stood by the rules and granted the radio spectrum bloc to the winner at the price proposed by the second. Clearly, such an outcome could be easily challenged by political opponents and ultimately undermine the bidding process.
} 
needs time to deliver social and economic outcomes. Second, bidders are not always rationale risk takers, and often engage in aggressive bidding strategies which finally deter the economic and financial viability of the projects bid out. The combination of all these factors weakens the political or social support to bidding outcomes. What should governments do to minimize these perceptions and anticipation gaps? Tenders are simple market based mechanisms which can be used to implement development programs in infrastructure sectors. As mechanisms to allocate resources, tenders should reflect social and political concerns in order to minimize these gaps. As discussed in Box 5, there is little that could have been done by the bidding process to address the social unrest generated by a reform program designed without sound consultations with all the stakeholders. Bearing this in mind, governments should not only emphasize transparency in the bidding process, but should also emphasize transparency and participatory process in designing and implementing infrastructure reforms ${ }^{8}$. An effective consultation process would have improved the social dimensions of the concession agreement and would have preserved the Cochambaba water concession from collapsing.

Box 5: Social unrest and the Cochabamba water concession

In 1999, the government of Colombia awarded a 40-year water concession to a consortium led by International Water from UK which was unfortunately the only bidder for the concession. To grant this concession to the private sector, a new law (law 2029 - the drinking water and sanitation law) was enacted. The law not only facilitated private sector participation, but it also ended subsidies to the water sector. Subsidies were in practice eliminated in January 2000 leading to a substantial rate increase of water. Opposition to the concession was formalized in January 2000 when a group of Cochabamba citizens formed a coalition and organized massive strikes. The coalition published a declaration calling for the reduction of water prices, the repeal of the water act, a ban on privatization and the repeal of the Cochabamba concession. The opposition to the reform grew stronger and stronger and ultimately led to the repeal of the water act in April 2000, as well as the withdrawal of International Water from the concession.

Source: World Bank (2003)

\section{Effective regulation ex-post}

The main purpose of regulation after the project has been awarded is to ensure and preserve the "sanctity of the bids". Regulation is an instrument or a mechanism used to hold contracting parties accountable for their respective commitments. For instance, the project developer should be held accountable of its bid, whereas the government should

\footnotetext{
${ }^{8}$ Governments can also consider stakeholders' participation in the bidding and decision making in order to mitigate these social risks. Of course, this entails the implementation of safeguard measures needed to preserve the confidentiality and integrality of the bidding process.
} 
be restrained from acting unilaterally. Ensuring regulatory certainty and its predictability throughout the concession period is the most important role devoted to infrastructure regulators. Regulating the behavior of the contracting parties is critical to achieve the project outcomes. Concession contracts should be well designed and balanced with respect to contractual obligations (service coverage, investment obligations, quality, and information requirement). Any discretion left to the regulator should be restricted to issues not explicitly stated in the contract. Furthermore, regulatory decisions should be subject to appropriate and effective appeal mechanisms. A well designed concession contract followed by poor regulatory oversight leads to deficient sector performance. Similarly, effective regulation alone is not sufficient to fix problems stemming from a poorly designed contract. As shown in Guasch (2004), concession contract renegotiations are much more frequent than one would imagine. Among the most critical issues arising after the concession has been awarded are issues such as: request for price adjustment or increase by operators, request for price freeze or reduction by governments, claims for minimum revenues guarantees as a result of excessively optimistic demand forecasts, and request to revise the pricing formulae. Failing to deal effectively with these issues prior or during the bidding stage will inevitably lead to renegotiations and eventually to deficient performance.

\section{Picking the right bidding process}

In the previous sub-section, the main issues likely to affect the success of a bidding process have been reviewed. This sub-section focuses on the selection of a bidding process in order to address these issues. Competitive tenders can be divided into two groups. Group 1 involves one stage bidding processes, whereas group 2 involves twostage bidding processes. In some countries, such as the UK and France, a three-stage bidding process is allowed under procurement regulation. In these countries, the granting or competent authorities can organize a third biding round during which preferred bidders submit their best available financial offer (BAFO). In general, to initiate a bidding process, governments can issue an invitation for expression of interest (EOI) in order to establish the level and type of interest of a particular project. But, an expression of 
interest is fundamentally different from a request for qualification (RFQ) as we will see in the case of a two-stage bidding process.

\section{a) One-stage bidding process}

A one stage-bidding process has at least two variants. In the first variant, proposals are solicited from interested developers (open bidding process). In the second variant, proposals are solicited from a restricted number of bidders (restricted bidding process). For restricted bidding processes, a short list of potential bidders is established on the basis of the experience, expertise and financial standing of each firm.

In general, one-stage bidding processes do not involve a formal pre-qualification stage despite the establishment of a shortlist of potential bidders. Bids are submitted in sealed envelopes enclosing two envelopes including the technical and financial proposals. The first envelope encloses the technical proposal, whereas the second envelope encloses the financial proposal. In some countries, such as in Korea, there is only one proposal including technical and financial components. Bids are submitted on a specified date, time and venue. The evaluation of bids is done according to the specifications provided by tender rules and procedures. The weights attributed to the technical and financial proposals are stated in the tender documents in compliance with the national procurement guidelines. For example, if bidders are likely to rely on the same technology to deliver the objectives of the project and the tender documents do not call for any substantial technology innovation, then financial proposals can be weighted up to $70 \%$ of the total score. Conversely, if technology or technical requirements call for substantial innovative solutions, then technical proposals can be weighted up to $70 \%$ of the total score. In sum, the weight given to technical and financial proposals in the evaluation of bids should be decided in connection with the primary objectives of the project. The bidder obtaining the highest total score wins the project. The evaluation of one-stage bidding process is time consuming, and gives substantial discretion to the evaluation team to interpret, compare and score competing proposals. 


\section{b) Two-stage Bidding Process}

There are many variants of two-stage bidding processes. However, the main feature of a two-stage bidding process is to include a formal pre-qualification stage. The prequalification stage is followed by the bid submission stage. As discussed earlier, the main objective of organizing a competitive bidding process is to select the project developer which is the most capable to deliver promised or anticipated outcomes in terms of services, prices, or coverage. In that context, the objective of the pre-qualification stage is to establish a list of technically and financially qualified bidders which can deliver the project development objectives. As opposed to restricted bidding discussed earlier in the case of one-stage bidding processes, the pre-qualification stage is a formal round of selection that aims to identify the most competent bidders. Only bidders meeting the requirements or criteria stated in tender documents will be invited to submit a bid.

However, determining the right number of bidders is not simple. For example, a twostage bidding process that does not attract more than two bidders will not ensure enough competition in bidding. Similarly, a two-stage bidding process for which more than five bidders are qualified may not induce competition in bidding because the probability to win the bid decreases with the number of pre-qualified bidders. As a result, determining the right number of bidders is a strategic decision that should take into account an assessment of the market conditions, the probability that some of the pre-qualified bidders may drop out of the bidding, and the sector specific conditions. There is no analytical rule or methodology to decide on the right number of bidders.

A study (ENGREF 2001) found that 3.5 bidders expressed their interest in tenders organized for the renewal of water concessions in France in 2000, of which 2.1 were qualified to submit bids. But, in 33\% of the cases, there was only one bid submitted. Another World Bank study (Foster, V. 2005) made comparable or similar findings in reviewing water concessions in Latin American countries ${ }^{9}$. Chart\#1 shows that the

\footnotetext{
${ }^{9}$ Foster, V (2005, p. 13): "Not only has the number of bidders for Latin American water contracts been comparatively small, but they have always tended to come from the same handful of predominantly French companies."
} 
number of potential bidders for water concessions is limited to 2 or 3 . With such a limited number of potential bidders, it is important to minimize the possibility of any bidder to withdraw from the bidding process ${ }^{10}$.

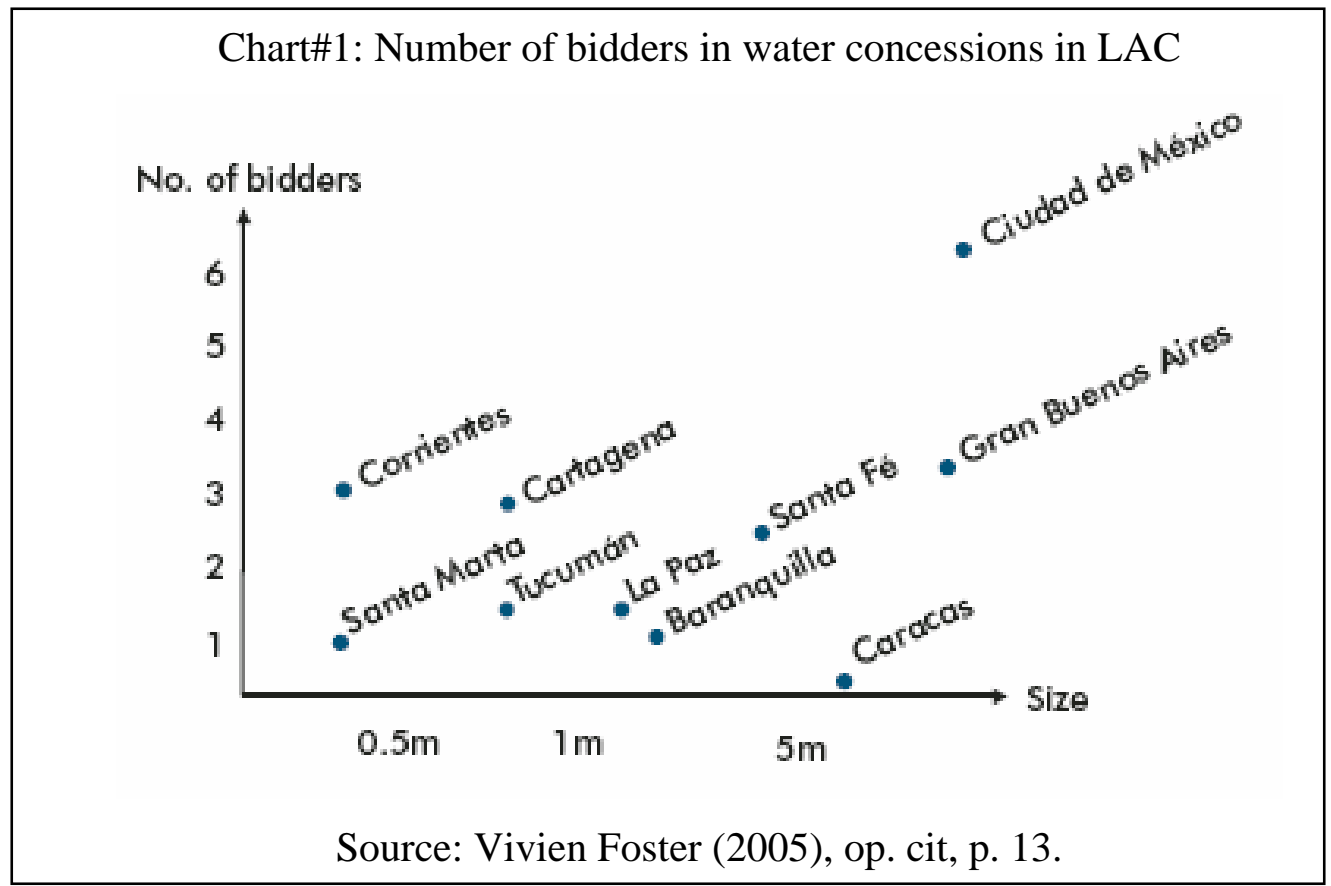

Chart\# 2 depicts the most important steps of a two-stage bidding process. The chart does not reflect the preparatory stage during which the government works closely with a team of advisors to define or decide on the project's configuration.

- The bidding process begins with the release of an expression of interest (EOI) by the government. The objective of an EOI is to check the interest of market players in a specific project being contemplated by the government. Potential bidders are given from 4 to 8 weeks to show their interest in the proposed project ${ }^{11}$.

\footnotetext{
${ }^{10}$ For PPI projects, the following bonds may be required: (a) conforming bid bond to ensure that the bidder will submit a compliant bid - indicative amount \#0.1 to $0.2 \%$ of capital costs - usually returned upon signature of the PPP agreement; (b) construction bond issued at financial close for the duration of the construction period - amount \# 2.5 to $3 \%$ of capital costs; (c) performance bond issued at the commencement of the operating period - amount \# 6 to 12 months of turn-over; (d) maintenance bond can also be required during the last years of the concession - project specific.

${ }^{11}$ The 4 to 8 weeks period allocated to EOI accounts for the need to assess the interest that potential investors may have on the project, and can be adapted to the size and complexity of the project. For
} 
- The government then issues the pre-qualification rules and procedures as well as the request for qualification (RFQ). The pre-qualification documentation may also include any other relevant documentation on the project, the legal and regulatory framework, and the macro-economic trends.

- Firms are given 3 to 6 weeks to prepare and submit their pre-qualification proposals. The government reviews the proposals and appoints the pre-qualified bidders. To ensure transparency, the evaluation prepared to support the qualification of firms should also be made public.

- After the pre-qualified bidders are known, the government can organize a formal consultation process to finalize the bidding documents ${ }^{12}$. The consultation process is done according to the tender rules and procedures and should help to ensure the adequacy of bidding documents to the market conditions and bidders' expectations. The consultation process can take between 8 and 16 weeks depending on the complexity of the project.

- The finalization of the bidding documents leads to the issuance of the request for proposals (RFP) or invitation for tenders. Pre-qualified bidders are given 8 to 12 weeks to prepare and submit compliant bids.

- The selection step in two-stage bidding process can be organized around two options. In option 1, bidders are requested to submit a bid enclosing technical and financial proposals. Both proposals are reviewed and evaluated according to criteria stated in the bidding documents. The bidder obtaining the highest score (technical and financial) wins the project or the concession. Such a selection scheme was successfully implemented in Morocco for the award of the second GSM license in $1999^{13}$. In option 2, which is illustrated in Chart 2, bidders are requested to submit bids enclosing their best available offer based on specified criterion or a combination of criteria. Bids are submitted, and opened and evaluated the same day. The negotiation of the concession agreement or contract

example, the granting authority can use that period to collect additional market and technical information required for the finalization of the project's specification.

12 - Only pre-qualified bidders are allowed to participate to these round of consultations.

13 - The license was granted to a consortium led by Telefonica (Spain) for US\$1.1billion. For this tender, the weights of technical and financial proposals were set at 40 and $60 \%$ of the total score respectively. 
can last from 6 to 12 weeks before the contract is signed. The final closure of the transaction can quickly follow when the sponsors have been successful to secure all the financing needed to develop the project. Usually, this step takes more time to close (see the Ashkelon project discussed in Box 2).

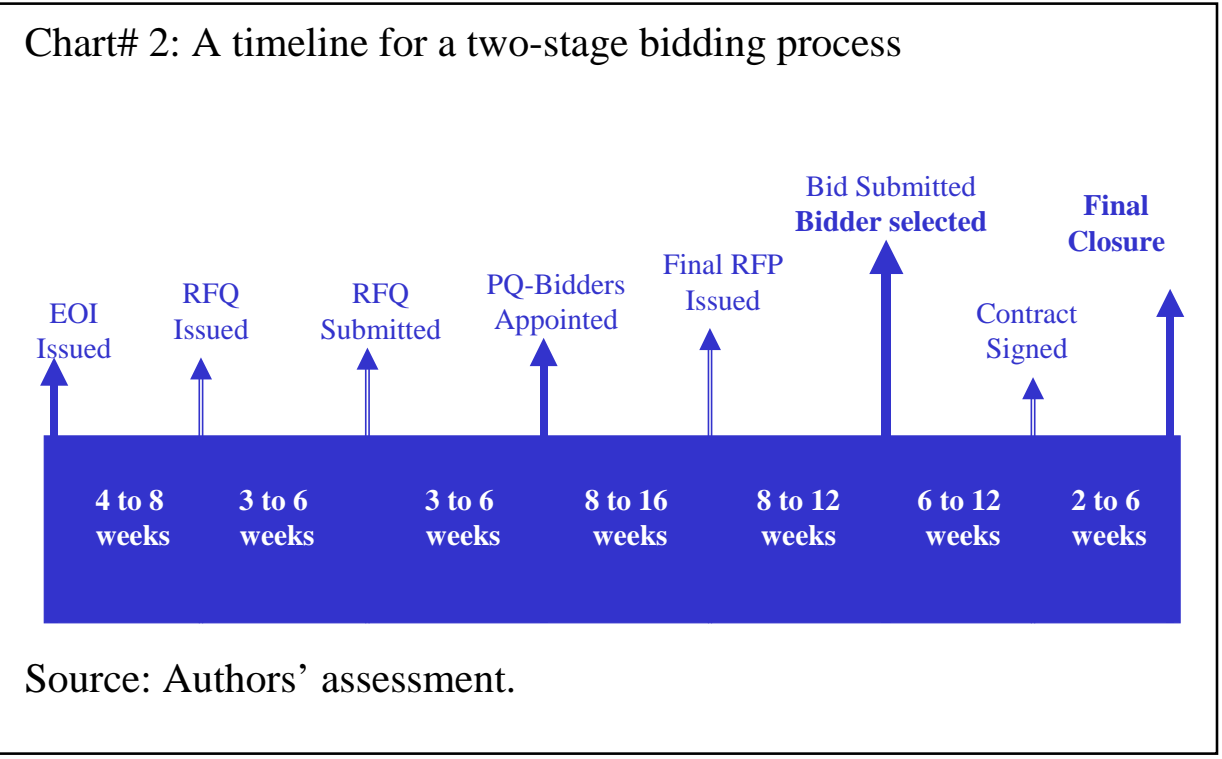

Table 1 provides a sample of selection criteria used in contemporary PPI tenders. As noted in Guasch (2004), governments are well advised to use a well crafted criterion to select the winning bidder. For example, the privatization of the electricity distribution company in Lima (Peru) was decided on the highest dollar value offered for the assets, but relying on such criterion can result in higher user fees. The government may also overlook social concerns and focus only on raising fiscal revenues. Similarly, a criterion such as "maximum discount to existing tariffs" which has been used in the privatization of water concession in Buenos Aires (Argentina) may also lead to aggressive bidding, thus increasing the opportunity for renegotiations after a winner has been selected. In an international context where water tariffs do not recover costs, it is hard to expect tariff discount if the goals of the reform are to expand coverage, improve quality and efficiency. Governments should be able to assess the regulatory trade-offs when designing concession contracts in order to ensure a balance between consumption affordability, expansion targets, and financial sustainability of the service providers. It is well accepted that there is no free lunch. Consequently, one cannot simultaneously get 
lowest prices and ambitious coverage targets. Economic and financial models are important decision making tools that policymakers or regulators should use for the reconciliation of all these objectives

Table 1: Examples of selection criteria
\begin{tabular}{|l|l|}
\hline \multicolumn{1}{|c|}{ Infrastructure transaction } & Structure of financial proposal \\
\hline $\begin{array}{l}\text { Peru : Lima electricity distribution } \\
\text { privatization }\end{array}$ & $\begin{array}{l}\text { Highest dollar value offered for } \\
\text { assets }\end{array}$ \\
\hline $\begin{array}{l}\text { Argentina: Buenos Aires water } \\
\text { concession }\end{array}$ & Maximum discount to existing tariffs \\
\hline Philippines: Power generation BOTs & $\begin{array}{l}\text { Lowest price (cents per kilowatt- } \\
\text { hour) of power to be supplied }\end{array}$ \\
\hline $\begin{array}{l}\text { Chile : south access to Conception } \\
\text { toll road }\end{array}$ & $\begin{array}{l}\text { Minimum toll and minimum one- } \\
\text { time subsidy }\end{array}$ \\
\hline $\begin{array}{l}\text { Turkey: electricity distribution } \\
\text { concession for Istanbul }\end{array}$ & $\begin{array}{l}\text { Minimum margin on distribution } \\
\text { required by the operator }\end{array}$ \\
\hline $\begin{array}{l}\text { Venezuela: Mobile telephony } \\
\text { concession }\end{array}$ & $\begin{array}{l}\text { Highest concession fee paid to } \\
\text { government }\end{array}$ \\
\hline
\end{tabular}

Source: Guasch (2004).

\section{The procurement of PPI projects in Korea}

In the first section we reviewed the principles and the main issues affecting the design and implementation of the procurement of PPI projects. This section reviews the experience of Korea in the development of PPI projects, and discusses more specifically how these projects are procured. South Korea is an attractive country for private investment in infrastructure sectors. The country credit worthiness ${ }^{14}$, the availability of local currency lending and the established track-record in managing infrastructure projects are its main assets.

\section{A. PPI project development in Korea}

Since the early 1960s, Korea has demonstrated an impressive record of economic performance. Much of its success stems from a commitment to infrastructure

\footnotetext{
${ }^{14}$ Standard and Poors sovereign rating for Korea: A+ (local) ; A- (foreign)
} 
development (Ro, Jaebong 2002) ${ }^{15}$. This success was facilitated by several factors including: strong leadership, efficient coordination for installing infrastructure facilities, and a well defined focus and priorities on infrastructure development. The government used a variety of public funding instruments to finance the development of infrastructure facilities. The main sources of funding for Korea's infrastructure development included: taxation, designated funds (special accounts), public pension funds, and private funds. Public financing of infrastructure projects was progressively replaced by private investments as shown in Table 2. As of September 2002, 75\% of PPI projects developed in Korea were financed by private investment and government subsidies represented around $25 \%$ of these investments. In fact, efforts to develop private investments in infrastructure were initiated in the early 1990s.

Table 2: Financing sources of PPI projects (Central Government) as of September 2002

\begin{tabular}{|l|c|c|c|c|c|}
\hline & Total Investment & $\begin{array}{c}\text { Government } \\
\text { subsidies }\end{array}$ & Private equity & Private debt & Others \\
\hline $\begin{array}{l}\text { KRW } \\
\text { billion }\end{array}$ & 34,438 & 9,794 & 7,186 & 17,972 & 486 \\
\hline$\%$ & 100 & 25.5 & 20.9 & 52.2 & 1.4 \\
\hline
\end{tabular}

Source: PICKO.

In 1994, the Private Capital Inducement Promotion Act was enacted to promote private participation in infrastructure, primarily Greenfield projects in transportation. This first PPI program was not a success because of substantial risks not properly mitigated. The government targeted 40 primary infrastructure facilities, but was only able to develop

\footnotetext{
${ }^{15}$ For instance, immediately after the Korean War, Korea focused on developing light industries and the country's import substitution capacity. Infrastructure to support these activities included the construction of 275 kilometers of railways and several small highway projects. Furthermore, to stimulate its exports Korea continued the emphasis on infrastructure development by expanding railways, highways and ports. Although the priority devoted to developing modern infrastructure was important during the 1960s, it is only after the country had achieved full employment in the 1970s and when it shifted to heavy and chemical industries that comprehensive policies and plans to develop infrastructure were adopted by the government. These programs involved the construction of major airports, seaports, highways, railways, and telecommunications systems to support the increasingly important manufacturing sector. Because of continuous efforts of the government, investment in infrastructure recorded an average increase of $20 \%$ every year during the 1990s prior to the financial crisis. In 2001, the percentage of infrastructure expenditures in the national budget reached $14.6 \%$.
} 
five of them. PPI projects were grouped in two categories: category-1 and category-2 projects. Category-2 projects included power generation plants, gas supply, bus terminals, tourism promotion areas, and sport complexes. Category-1 projects involved more strategic infrastructure projects such as roads, railways, subways, ports, airports, water supply and telecommunications. The private sector could obtain ownership only in category-2 projects. As a result, category-1 projects could be carried out only through Build Transfer Operate (BTO) scheme, whereas category-2 projects were eligible for a broader scope of options including Build Operate and Transfer (BOT), and Build Transfer and Lease. In July 1998, the Planning and Budget Committee announced policies to privatize 11 state enterprises including Korea Telecom and Korea Electric Power Corporation and Korea Gas Corporation, and to create a new regulatory framework for private participation in infrastructure.

\section{Box 6: Traditional Planning Institutions are no longer adequate.}

The Economic Planning Bureau (EPB) was the coordinating agency in the infrastructure decision making process. Its responsibilities covered a wide range of activities in infrastructure development and operations including the coordination of ministerial plans, making policy recommendations, and allocating budgets. Several other ministries were also responsible for planning and managing infrastructure, namely, the Ministry of Transportation for rail and ports; the Ministry of Construction for highways, housing, dams and water; the Ministry of Industry, Energy, and Resources for electricity and gas; the Ministry of Communications for telecommunications and the Ministry of Environment. Local governments were responsible for local and urban transportation. However, the President's office - the core of the government's power base - made the most important decisions. This extensive set of institutions served Korea well in the past, but does not seem to be adapted to help the country address the most critical issues raised by the expansion or modernization of infrastructure.

Source: adapted from Jaebong Ro (2002), "Infrastructure development in Korea", paper prepared for the PEO structure specialists meeting - Infrastructure development in the Pacific Region, September 23-24, Osaka, Japan, mimeo, 28 pages

The PPI Act was enacted in 1999. The Act encouraged private participation in the power, gas, transportation, airports, ports, telecommunications, water and sewage sectors by providing tax and other incentives to private investors, and by improving the procurement process. The Act also included incentives for foreign investors such as: (i) a 10 percent value-added tax exemption, (ii) a government guarantee of up to 90 percent of operating revenues, (iii) a bonus for early completion of construction, (iv) the compensation for losses due to exchange rates fluctuations, (v) a buy-out option in case of force majeure. In addition, the Act abolished the former categorization of infrastructure projects and 
enhanced transparency in the procurement of PPI projects. Moreover, the Act established PICKO as a specialized agency to provide technical assistance to competent authorities on the preparation of feasibility studies and on the preparation of PPI projects tenders. More specifically, $\mathrm{PICKO}^{16}$ was responsible for the review of feasibility studies prepared by competent authorities (ministries and local government), and was also in charge of the evaluation of bids. Finally, a ten-year PPI plan listing priority PPI projects was prepared by the government. The 10-year plan includes priority projects pre-identified as such and for which competent authorities have prepared pre-feasibility studies (see Annex I). Chart\# 3 shows that local and central governments have been increasingly involved in developing PPI projects. These projects involved major urban infrastructures such as bridges, expressways, tunnels, and water treatment plants.

Chart\# 3: Number of PPI projects approved

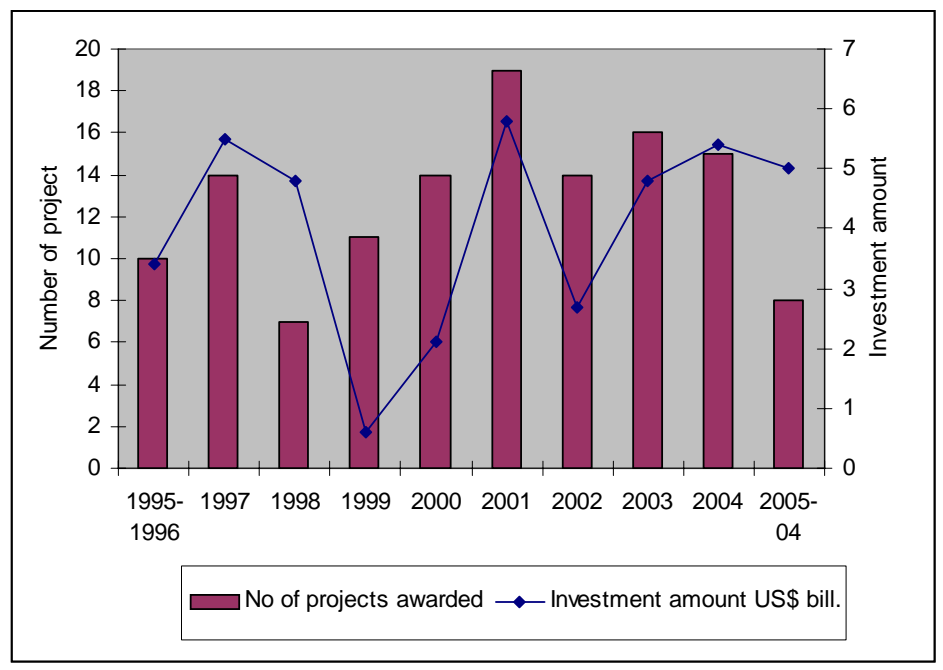

Source: PICKO (2005)

Additionally, bank financing of PPI projects also increased tremendously. As shown in Chart\# 4, bank financing of PPI projects reached a total of KRW 20,000 billion in 2002 compared to KRW 2,500 billion in 1995 when the first PPI legislation was enacted. But

\footnotetext{
${ }^{16}$ In January 2005, the government of Korea passed an amendment to the 1999 Act establishing PIMAC as the new PPI unit. The amendment also introduced the following changes: (a) inclusion of social infrastructure such as schools, housings in the list of sectors eligible to PPI, (b) introduction of BTL (Build Transfer and Lease), (c) creation of an Infrastructure Fund, (d) requirement to assess the value for money for all PPI projects, (d) PICKO of KRIHS and PIMA of KDI are merged into PIMAC to be hosted by KDI.
} 
most bank financing went to projects supported by the central government whereas the number of projects promoted by local governments has remained predominant.

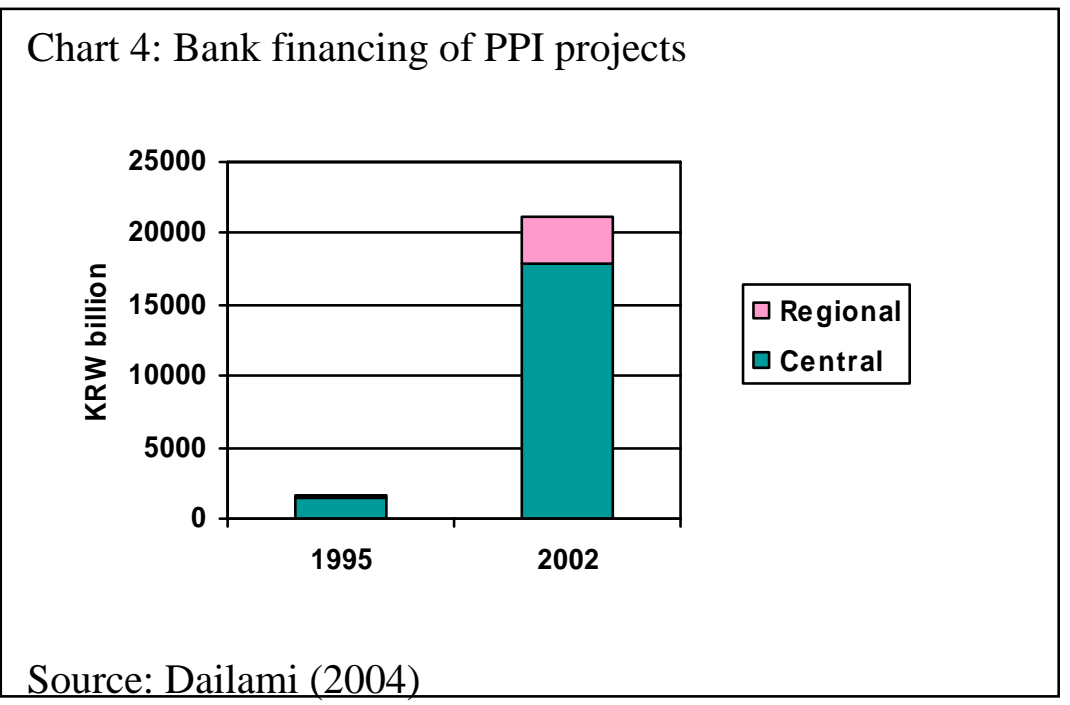

\section{B. Procurement of PPI projects in Korea}

In Korea, the rules and procedures regulating the procurement of PPI projects are spelled out in the 1999 Act, and in its Enforcement Decree. This sub-section reviews these rules and procedures.

\section{One-stage bidding process}

According to the Act, competent authorities are responsible for the designation of concessionaires in charge to develop PPI projects. To do this, local governments must organize competitive tenders according to the rules and procedures spelled out in the enforcement decree of the 1999 Act. The procurement of PPI projects follows an open sealed-bid tender even though competent authorities can implement a pre-qualification stage. Consequently, the number of potential bidders remains unknown until the submission of bids. Furthermore, bids are made of one proposal which includes technical and financial components. In fact, the procurement rules do not differentiate technical from financial proposals. Proposals are prepared according to article 12 of the enforcement decree, and should reflect the following key elements:

- contents of the project proposal including basic engineering plans 
- details of the total project costs and financing plan

- justifications for the cash-flow estimates

- management and operation plans for the facility

- justifications for expenditures plans and revenues estimates

- contents for implementing supplementary projects

- contents for subsidy request if any.

Bids are evaluated according to a set of criteria spelled out in article 13 of the decree and summarized in Table 3.

Table 3: Categories for the evaluation of bids

\begin{tabular}{|l|l|c|}
\hline & \multicolumn{1}{|c|}{ Content } & Score \\
\hline Category 1 & $\begin{array}{l}\text { Composition of the concessionaire, such as organization types, } \\
\text { relationship between sponsors }\end{array}$ & 50 \\
\hline Category 2 & $\begin{array}{l}\text { Feasibility of the project proposals, such as project costs, } \\
\text { construction period, site, content of construction }\end{array}$ & 150 \\
\hline Category 3 & Financing plan, such as equity and debt financing capacity & 300 \\
\hline Category 4 & $\begin{array}{l}\text { Economic feasibility of the project, such as user fees, } \\
\text { concession period, rate of return, scale of supplementary } \\
\text { projects }\end{array}$ & $\begin{array}{l}\text { Facility management capability, such as the appropriateness of } \\
\text { the maintenance plan, the operation and management plan, land } \\
\text { acquisition }\end{array}$ \\
\hline Category 5 & $\begin{array}{l}\text { Contribution to social benefits, such as the provision of services } \\
\text { to the facility users }\end{array}$ & 200 \\
\hline Category 6 & \multicolumn{1}{|c|}{100} \\
\hline Total score & & 1000 \\
\hline
\end{tabular}

Source: PICKO (2004).

Bids obtaining a total score below 600/1000 points or bids which do not score above 60/100 point on category 3 are disqualified. The competent authority then selects at least two preferred bidders with which competitive negotiations are organized. Negotiations can involve up to 30 preparatory meetings which are followed by 5 to 7 negotiation rounds. The best available offer results from these negotiations which can take up to 52 weeks. Overall, the procurement of PPI projects takes on average 4 years to complete whereas international experience shows an average timeline on or around 88 weeks.

\section{A legacy of civil works procurement}

Rules and procedures applied to the procurement of PPI projects are influenced by rules and procedures originally developed for the procurement of civil works. As shown in Table 3, the evaluation of bids relies heavily on the means (technical and financing) to be 
mobilized by the project developer, whereas the procurement of PPI projects should be outcomes oriented. In Table 2, only 300 points over a total of 1000 points are allocated to assess the ability of potential bidders to deliver the outcomes of the projects. The rest of the evaluation concentrates on insuring that potential bidders can mobilize required means or resources to develop the PPI project. For example, category 4 is allocated 200 points despite the fact of it involves most of the project development outcomes on which bidders should be kept accountable for. In Korea, outcome oriented criteria represent between $20 \%$ and $40 \%$ of the total evaluation's score. This is very low in comparison to international best practices in the procurement of PPI projects. Furthermore, the public procurement agency can verify the project costs to ensure the appropriateness of unit prices whereas in a concession such a responsibility lies primarily with the project developer.

\section{PPI market inefficiencies}

This sub-section reviews the inefficiencies of the PPI market in Korea as these are perceived by most national and international observers.

\section{A high number of unsolicited proposals}

The Korean PPI market is characterized by an astonishingly higher number of unsolicited proposals. Between 1999 and 2003, the number of solicited projects grew from 7 to 12, whereas the number of unsolicited increased from 5 to 39. The multiplication of unsolicited proposals is quite difficult to explain. The first reason that one can suggest is the weak capacity of competent authorities. More specifically local governments are ill equipped to prepare the feasibility studies requested for the designation of PPI projects. Furthermore, most competent authorities do not have sufficient budget to contract out the

preparation of such studies to specialized consultants. Because of these weaknesses, initiators of unsolicited proposals prepare feasibility studies and subsequently submit them to competent authorities as unsolicited proposals. The second reason relates to the fact the Korean procurement regulations do not formally exclude from unsolicited proposals, projects which have been included in the ten-year PPI plan. The designation of PPI projects follows a procedure specified by the enforcement decree (see Annex I). Under this procedure, preliminary feasibility studies must be prepared by competent 
authorities to demonstrate the project eligibility to private investment participation. The 10-year PPI plan therefore includes projects for which preliminary feasibility studies have been prepared, even though these projects are not yet designated PPI projects. Projects will be designated PPI projects only after the completion of conclusive feasibility studies. Consequently, until a project is designated as a PPI project by a competent authority, it can be presented as an unsolicited proposal. Private operators take advantage of this loophole.

\section{Domination of local construction firms}

The PPI market in Korea is dominated by five main construction and engineering firms: Samsung, Daewoo, Posco, Hyundai and Kumbo construction. The domination of these local firms is not surprising. Korean construction firms are globally very competitive on international markets, and are well positioned to dominate their domestic market. More interestingly, these firms provide the initial capital investment needed to develop PPI projects even though they are only interested in the construction phase of the project. Moreover, Korean construction firms establish consortia with the implicit objective to limit competition in downstream PPI projects tenders. The strong domination of local construction firms also explains the limited involvement of foreign firms. Out of 149 projects awarded from 1994 to 2004, only 12 involved foreign firms. The participation of foreign firms is estimated at US\$887million or $2.3 \%$ of the total PPI investment in Korea $^{17}$. The low level of the participation of foreign firms is further explained by a variety of additional reasons.

\section{Options to improve the procurement of PPI projects in Korea}

Korea is facing two major challenges in its efforts to develop a vibrant PPI market. The first challenge is to eliminate the inefficiencies which are still characterizing its PPI market (cartelization, lack of world class developers, concentration in the supply market). The second challenge relates to government policies and more specifically to its current

\footnotetext{
${ }^{17}$ Foreign participation is distributed between US\$279million equity participation and US\$642million debt participation. This includes 6 projects in roads or expressways, 1 harbor project, 2 light rail transport projects, 3 subways transit systems.
} 
procurement rules and procedures. This section provides some recommendations to address inefficiencies identified.

1. Make two-stage bidding process compulsory for large and complex PPI projects

The procurement of PPI projects is about selecting the most capable project developers to deliver the project's objectives. This implies two changes in the procurement regulations. The first change is to streamline the bidding process in a way that reduces the cost of preparation of compliant bids. The second change is to make two-stage bidding process compulsory for large and complex PPI projects. The introduction of a two-stage bidding process with a mandatory pre-qualification stage will be an effective tool to address issues pertaining to the cartelization of the supply, as well as enhancing the selectivity of project developers. Potential bidders will be screened and scrutinized against technical and financial requirements during the pre-qualification stage. Pre-qualified firms will submit bids on the basis of a well crafted criterion, thus streamlining the selection of the winner. Similarly, security mechanisms such as performance bonds, penalties for delays, incentives for improved performance and balanced contractual termination clauses will bring additional comfort to the government regarding the ability of the bidders to fulfill their commitments. As a result, the use of one-stage bidding process will be restricted to more straight forward or small scale PPI projects.

\section{Introduce more stringent regulations on unsolicited proposals}

The number of unsolicited proposals is abnormally high in Korea. Further research to understand why there are more unsolicited than solicited proposals in Korea would be a worthwhile exercise. Unsolicited proposals should be the exception and not the norm. For example, the Philippines' BOT law conditions the eligibility of unsolicited proposals to the following criteria:

(i) the project should be innovative (new concept or technology),

(ii) the project should not be listed in the list of priority projects issued by the government; 
(iii) the project should not involve any direct government guarantee, subsidy or equity;

(iv) the government agency or the local government unit should publish an invitation for competitive proposals in a newspaper of general circulation;

(v) the initiator of an unsolicited proposal does not receive any preferential treatment, even though she has the right to match any competitive offer that may be subsequently submitted.

In Korea, the high number of unsolicited proposals illustrates the capacity of the private sector to opportunistically abuse the procurement guidelines. Thus, the need to restrict unsolicited proposals to innovative projects or PPI projects planned in economically disadvantaged regions. In order to reverse the observed trend, private sponsors should not be allowed to pick unsolicited projects from the PPI plan published by the government. Besides, the initiator of an unsolicited proposal should not be given any other preferential treatment than the right to match any competitive bid that might materialize.

\section{Introduce more stringent regulations on the formation of consortia}

International experience shows that many PPI projects have run into problems because the shareholders' agreement did not stand the test of time. The long run sustainability of shareholders' agreement is among the critical issues governments should be aware of, and should be able to address during the bidding process. Among possible regulations to be introduced, we suggest the following:

- Request the incorporation of shareholders' agreement in the tender documents. Doing this will provide the competent authority with relevant information about the allocation of responsibilities between sponsors.

- Impose restrictive conditions (no change in shareholders for a minimum number of years, consent from granting authorities) on changes in shareholders to secure long term commitment of the project's sponsors.

- Request the incorporation of a dispute resolution mechanism in shareholders' agreement. 
- Request bid and performance bonds to contain the ability of sponsors to walk out of the project.

The enforcement of these regulations will also limit the scope of collusion in the procurement of PPI projects.

\section{Enhance regulatory oversight on PPI contracts}

A well designed PPI contract followed by a poor regulatory oversight leads inevitably to deficient sector performance. Although effective regulation is not a sufficient condition to fix all the problems arising from poor contract design, it is a powerful tool to ensure the sanctity of bids, and to hold the winning bidder and the government accountable. As shown by Guasch (2004), the existence of an autonomous regulatory agency has the largest marginal effect on the outcomes of PPI tenders. In Korea, regulatory oversight has been deficient in most infrastructure sectors, thus probably explaining the disappointing performance of some PPI projects as illustrated by the increasing claims of minimum revenue guarantees (Chart 5).

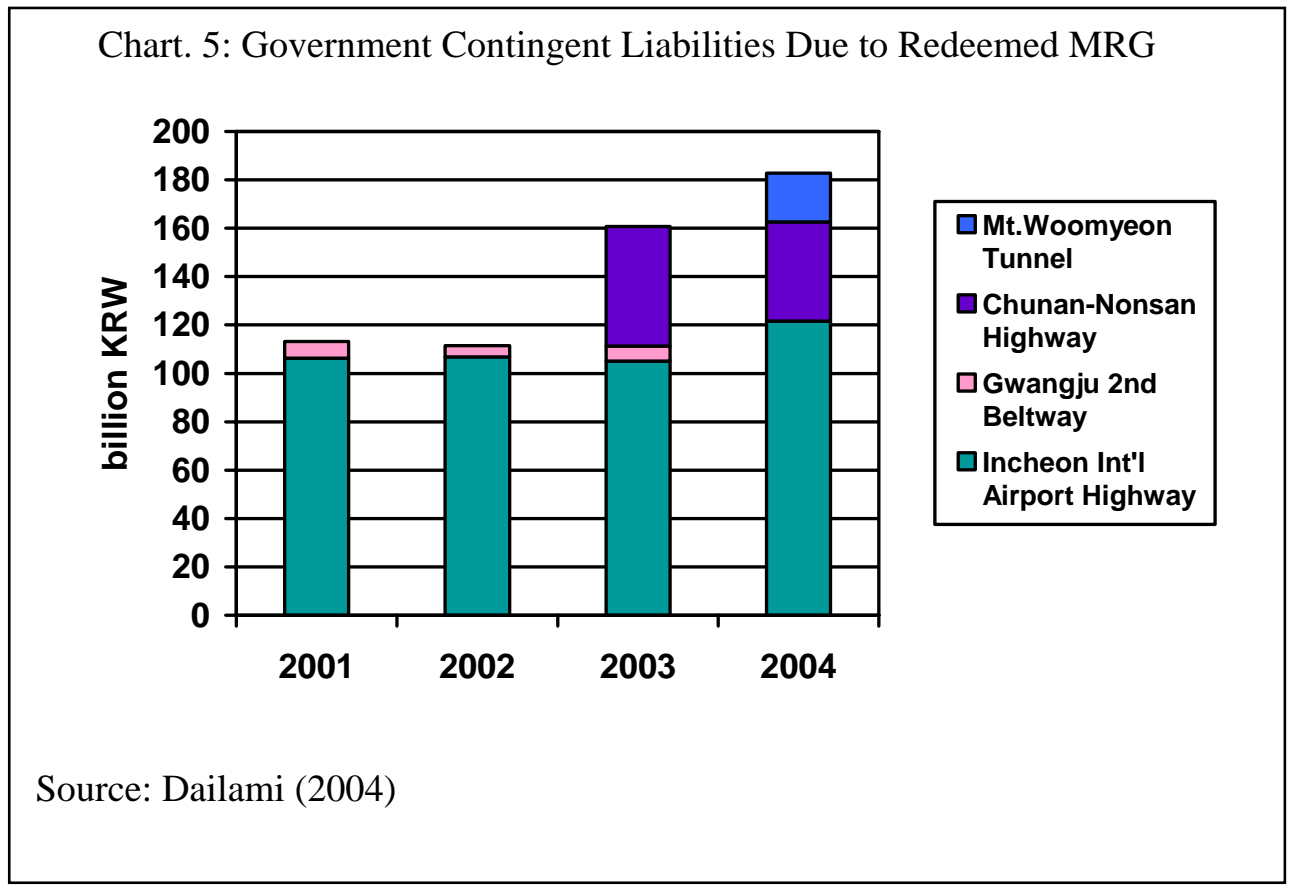


5. Shift government's support from construction firms to project developers

Korea still lacks world class project developers. The government faces a dilemma between relying on construction firms to develop the PPI market, and the need to ensure long term project viability by relying on world class project developers. Developing a world class category of project developers in Korea entails the combination of some of the measures already discussed. For example, the reliance on a two-stage bidding process and the introduction of more stringent regulations over the formation of consortia will direct bidders' incentives towards setting-up special purpose entities with long term orientation.

\section{Conclusion}

During the past 15 years most governments have implemented policies to promote private sector participation in infrastructure sectors. Korea has also relied on public-private partnership to expand and modernize its infrastructure facilities. Despite progress to date, important challenges still need to be addressed by the government to achieve the longterm sustainability of the PPI program. The paper has shown that bidding out PPI projects is a complex, time consuming and a politically sensitive process, and has emphasized the need to ensure certainty, predictability and selectivity of the bidding process in order to reduce the costs of preparing compliant bids, and ultimately induce competition in bidding. The PPI market in Korea is still confronted by critical challenges involving market inefficiencies, such as the cartelization of the construction industry and the lack of capacity of most competent authorities to organize bidding processes and oversee concessionaires in charge of developing PPI projects. Korea also needs to address the inefficiencies characterizing the procurement of PPI projects. The paper suggests specific measures to address these inefficiencies such as: (i) shifting from a one-stage to a twostage bidding process in the case of large and complex PPI projects; (ii) introducing more stringent regulations on the formation of consortia and on unsolicited proposals; and (iii) enhancing the oversight of PPI contracts by developing effective regulatory institutions. 


\section{References}

Demsetz, Harold (1968), “Why regulate utilities?” Journal of Law and Economics, 11, pp. 55-65.

Dailami, M. (2004), Korea’s PPI market: Financing source, growth potential and new challenges, mimeo.

Foster, V. (2005), "Ten years of water service reform in LAC - toward an Anglo - French Model”, January, Water Supply and Sanitation Sector Board Paper No 5

Harada, Fumiyo (2004), "Legal framework for private participation in infrastructure in the selected East Asian Countries - Comparative study on Japan, Korea, and the Philippines”, 28 pages, mimeo.

Jose Luis Guasch (2004), Granting and renegotiating infrastructure concessions - doing it right, WBI Development Studies, The World Bank

Kerf, Michel and al (1998), Concessions for infrastructure - A guide to their design and award, World Bank Technical Paper No 399, 131 pages.

Klemperer, Paul (2002a), How (Not) to run Auctions: the European 3 G telecom auctions, The European Economic Review, Volume 46, Issues 4-5, May, pp. 829-45.

Klemperer, Paul (2002b), "What really matters in auction design", Journal of Economy Perspectives, 16 (1), pp. 160-189.

Laffont, Jean-Jacques and Tirole, Jean (1993), A theory of incentives in procurement and regulation, MIT Press.

Michael Klein (1998), “Bidding for concession”, World Bank Policy Paper Series 1957

National Treasury South Africa (2004), PPP manual - module 5: PPP procurement

PICKO (2004), Developing best practice for Korea's PPI market - with a focus on PSC, mimeo, 370 pages

Williamson, O. E. (1976), "Franchise bidding for natural monopolies - in general and with respect to CATV”, Bell Journal of Economics, 7 (1), spring.

World Bank (1998), Bidding for private concessions - the use of World Bank guarantees, RMC Discussion paper 120. 


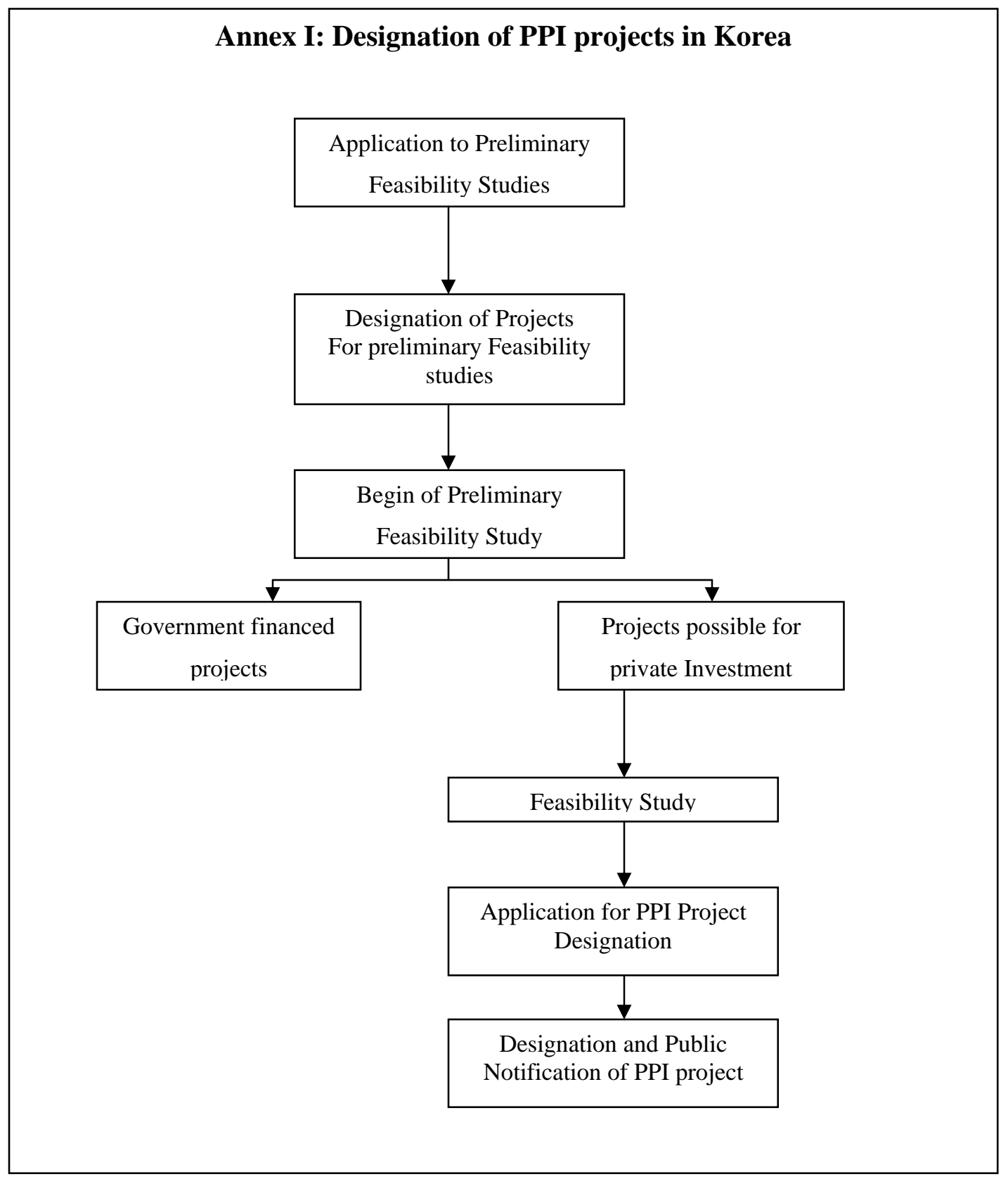




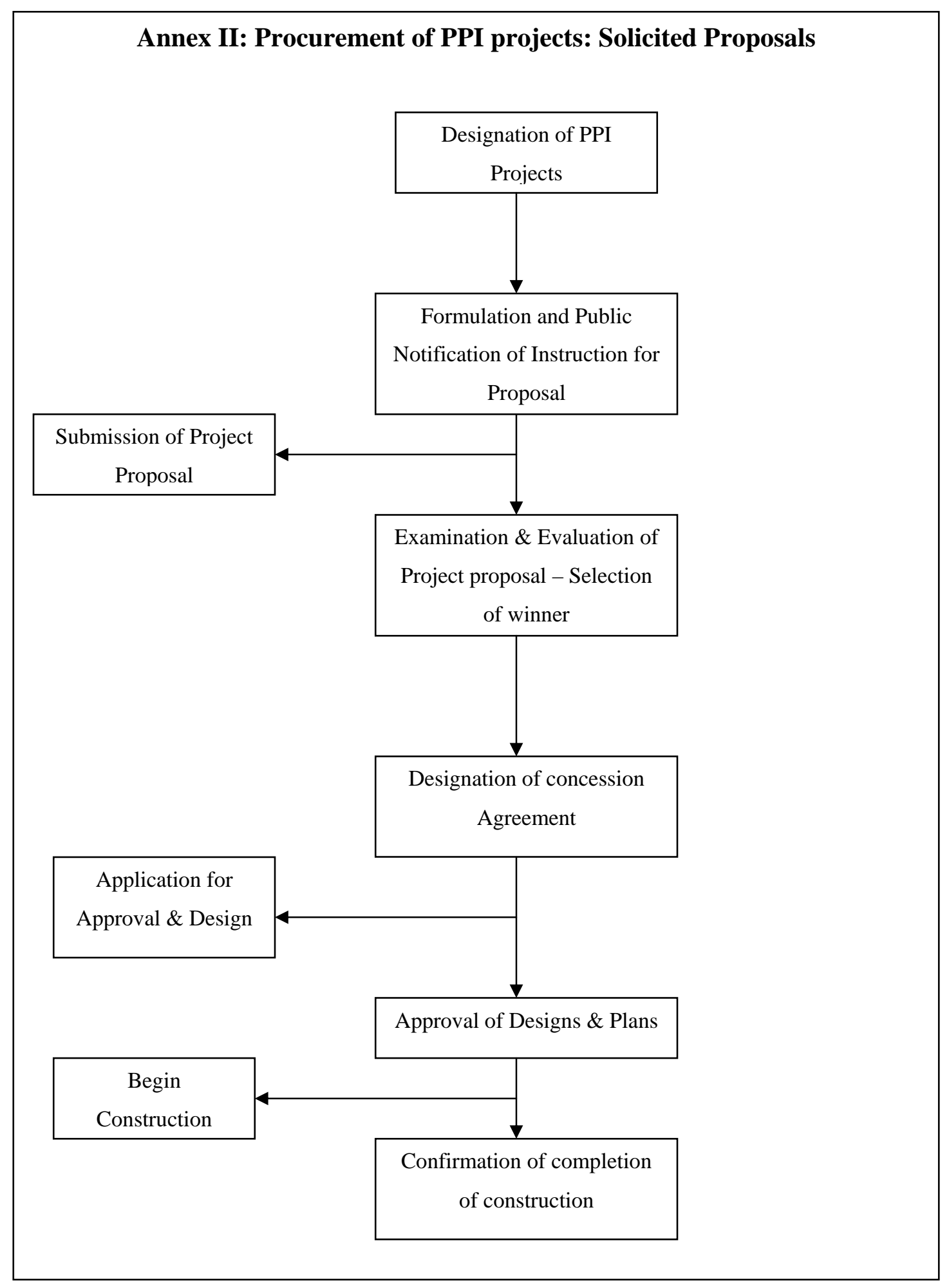




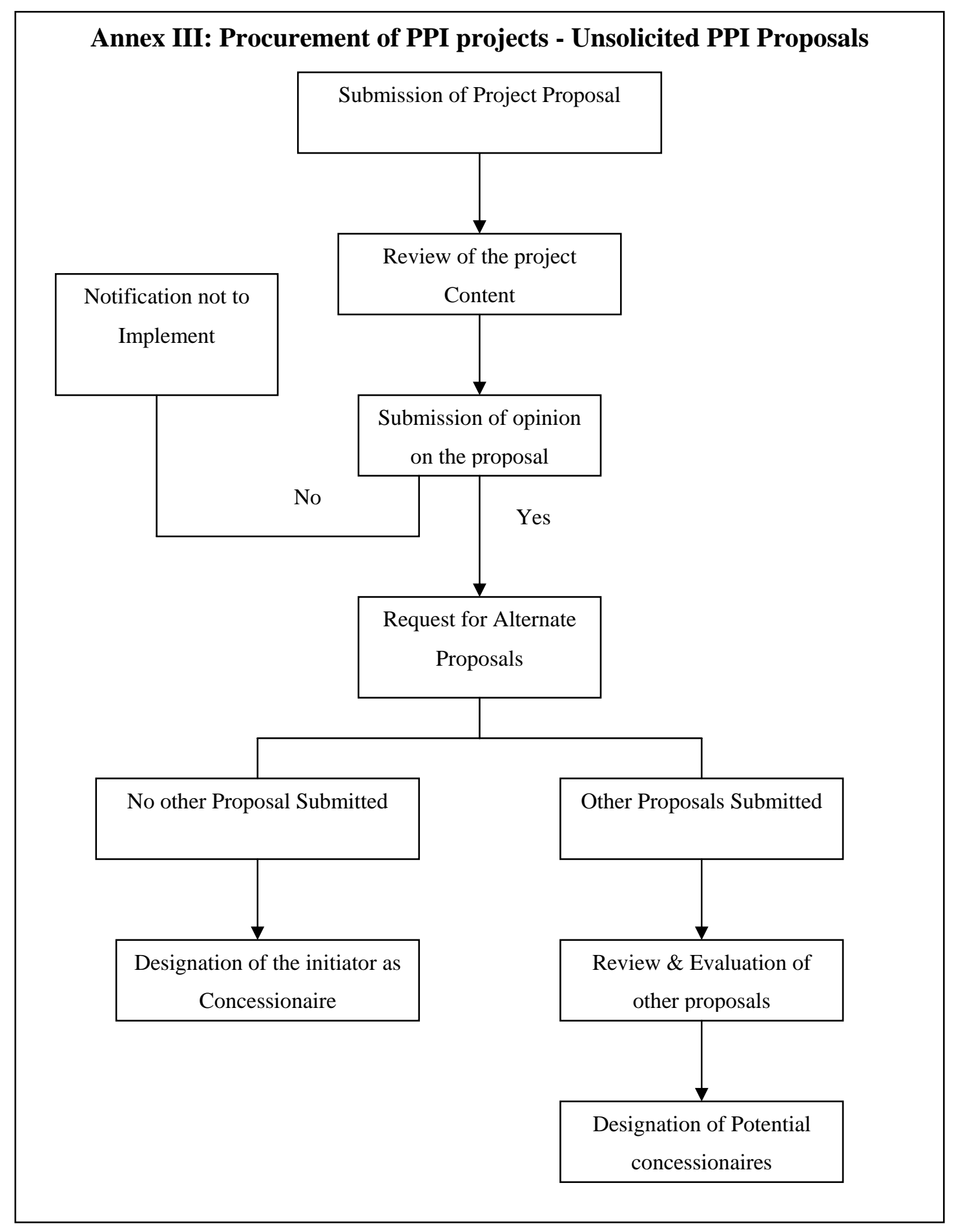

